Ind. Health, 1975, 13, 37.

\title{
RESPONSES OF ALVEOLAR MACROPHAGE TO METALLIC FUME
}

\author{
Kimiko KOSHI, Katsunori HOMMA and Hiroyuki SAKABE \\ National Institute of Industrial Health, Kizuki-Sumiyoshi, Nakahara-ku, Kawasaki
}

(Received April 16, 1975)

\begin{abstract}
Alveolar macrophage was lavaged from lungs of rats exposed to inhalation of the particles of $\mathrm{Sb}, \mathrm{Pb}, \mathrm{Cd}, \mathrm{CaCO}_{3}$ or poly vinyl chloride (PVC) and its number and ${ }^{14} \mathrm{C}$-leucine incorporating activity were studied. The number of free cell lavaged from the lung decreased remarkably by the exposure to $\mathrm{Sb}$ or $\mathrm{Cd}$ fume, while by the exposure to $\mathrm{Pb}$ fume, $\mathrm{CaCO}_{3}$ or $\mathrm{PVC}$ particles the number of lavaged cells did not change from that of control group breathing air in the exposure chamber. There was found a linear correlation $1 \mathrm{hr}$ after inhalation between ${ }^{14} \mathrm{C}$-leucine incorporation value for total cell and the number of lavaged cell in all the experimental groups except unrestrained (bred freely under normal condition) group and Sb group. That is, the incorporation value per cell in all the experimental groups except Sb group and unrestrained group was almost equal. In the case of Sb group and unrestained group the incorporation value per cell was lower than those of the other groups. Although the incorporation of ${ }^{14} \mathrm{C}$-leucine into cell in control group decreased by level of unrestrained group $21 \mathrm{hr}$ after inhalation, in the $\mathrm{Pb}, \mathrm{CaCO}_{3}$ or PVC group ${ }^{14} \mathrm{C}$-leucine incorporation into cell 21 th hour did not change from that $1 \mathrm{hr}$ after inhalation. ${ }^{14} \mathrm{C}$-leucine incorporation per cell in Sb group $21 \mathrm{hr}$ after inhalation remarkably increased. This tendency was also seen in Cd group.

The effects of the particles used in the inhalation experiment on the macrophage in vitro were also studied. The Sb fume was the most effective of all the samples and followed by $\mathrm{Cd}$ fume and then by $\mathrm{Pb}$ fume. The particles of $\mathrm{CaCO}_{3}$ or $\mathrm{PVC}$ were practically inert to the macrophage.
\end{abstract}

It may be assumed that the first reaction of cells to inhaled particles in the alveolar cavity is phagocytosis by alveolar macrophage. For this reason the number and activity of alveolar macrophage are thought to be important aspect in pulmonary defence.

We reported previously ${ }^{1 \sim 3}$ effects of various dust particles on the macrophage in vitro. It was doubtful whether there was a correlation between the toxicity of various particles to macrophage in vitro and the toxic action of these particles to alveolar macrophage in vivo.

In the present paper we observed the cellular toxicity of metallic fume and dust particles in vitro and also the number and activity of alveolar macrophage lavaged from the lung of rat that had inhaled the same particles. 


\title{
K. KOSHI, K. HOMMA AND H. SAKABE
}

\author{
MATerial AND Method
}

\section{Animal}

Sprague-Dawley male rats weighing between $260 \mathrm{~g}$ and $280 \mathrm{~g}$ (about 8 weeks old) were used for inhalation experiments. Up to the experiment they were breeded in all fresh air conditioned room with $23 \pm 1^{\circ} \mathrm{C}$ temperature and $50 \pm 5 \%$ relative humidity and were given sterilized commercial pellet and sterilized tap water freely.

\section{Macrophage}

1. Peritoneal macrophage. The macrophages were obtained from intraperitoneal exudate induced in rats by intraperitoneal injection of sterile Tyrode's solution containing $0.001 \%$ glycogen and then the cells were washed 2 times with Tyrode's solution. The cells were suspended in Tyrode's solution in a concentration of $1 \times 10^{7}$ cells $/ \mathrm{m} l$.

2. Alveolar macrophage. The rats were lightly anesthesized with ether and then were sacrificed by cutting the abdominal aorta. The chest cavity was opened and the trachea was ligated to prevent the entry of blood into lungs and then the lung and trachea were removed from the thoracic cavity. A vinyl cannula was introduced into trachea and connected to a syringe containing a measured volume ( $5 \mathrm{ml}$ per $\mathrm{g}$ lung) of isotonic saline solution. The solution was allowed to run into the lung and then the lung was inversed. The washing procedure was repeated 4 times. The total cell number was calculated in hemocytometer and the cells were suspended in Tyrode's solution.

\section{Dust particles}

1. Poly vinyl chloride particles. Poly vinyl chloride particles (PVC) were produced by emulsion polymerization procedure. (Nippon Carbide Industries Co. Inc.) These particles did not contain any plasticizer.

2. Calcium carbonate. Calcium carbonate purchased from Wako Pure Chemical Industries Ltd. (first grade).

\section{Generation and dusting method of metallic fume or dust}

The lead $(\mathrm{Pb})$, antimony $(\mathrm{Sb})$ and cadmium $(\mathrm{Cd})$ fumes were used in non-oxidized metallic state, These metallic fumes were generated with the high frequency induction furnace from each sample metal. The purity grade of the metal $\mathrm{Pb}, \mathrm{Sb}$ and $\mathrm{Cd}$ (Ohsaka Asahi Metal Co.) was $99.999 \%$. The details of generation procedure of metallic fumes were described previously.4)

The dusting of the particles of PVC (Poly vinyl chloride) and $\mathrm{CaCO}_{3}$ were carried out with centrifugal type dust feeder which remodeled an electric juicer.

The generated fumes or dusts were introduced into the exposure system. The exposure system was shown in Fig. 1. The mean concentration of generated fume or dust in the exposure chamber was determined from the weight of the particles collected on the filter paper in the monitoring impactor. During the exposure the fluctuation of 


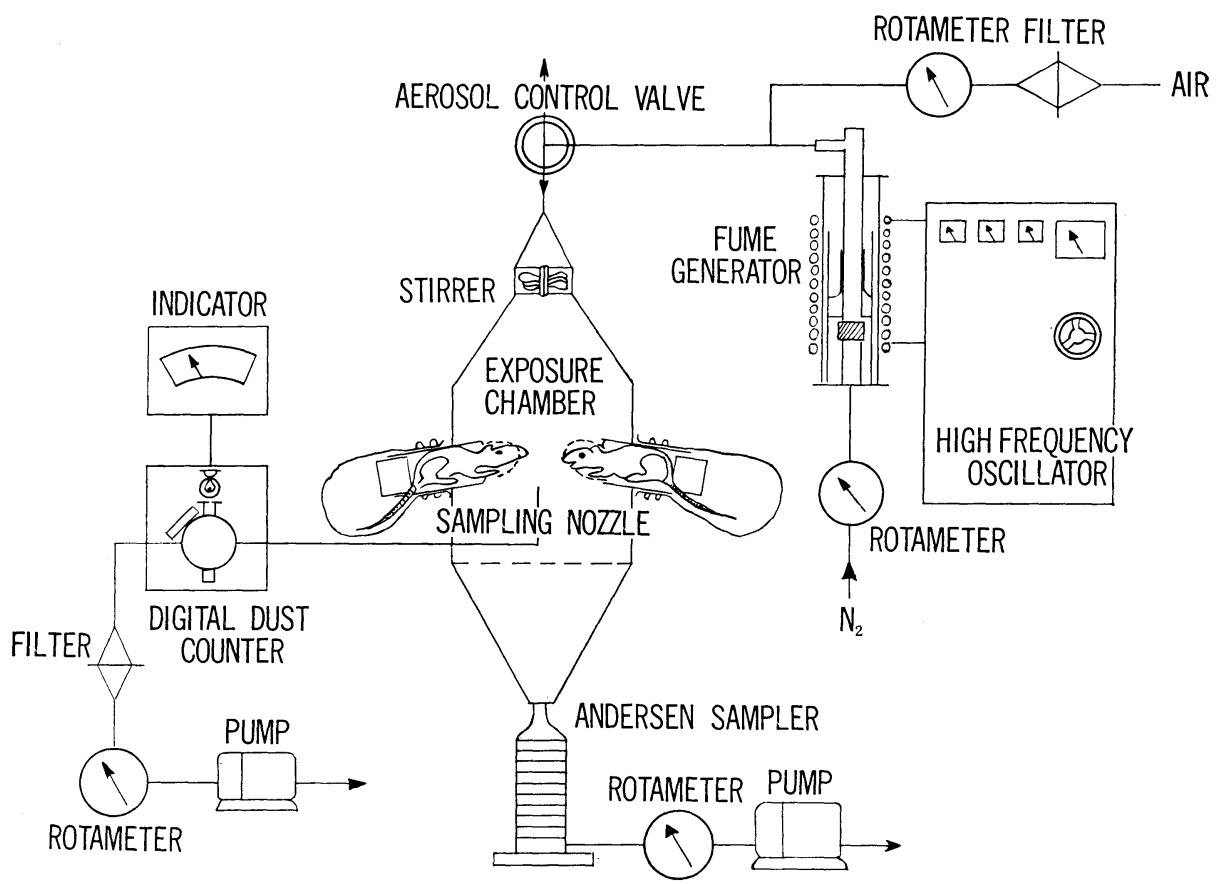

Fig. 1. Blockdiagram of metallic fume inhalation apparatus.

the mean concentration of fume or dust was kept within $10 \%$. The particles that passed through the exposure chamber were collected by the Andersen sampler. The particle size distribution of fume or dust was estimated by measuring weight of the particles in each stage of Andersen sampler. In order to ascertain the shape of the particles during inhalation, the particles in the chamber were collected on the specimen grid by the impactor every $30 \mathrm{~min}$. and were observed with an electron microscope. These electron micrographs were presented in Fig. 2.

\section{Method of inhalation}

The characteristics of the exposure chamber used in this experiment were described previously.5) When a stable state in the fume or dust concentration was attained, 6 rats were charged with inhalation. Ninety minutes were used as exposure time in all the inhalation experiment except the case of cadmium. In the case of $\mathrm{Cd}$ inhalation $30 \mathrm{~min}$ were used as exposure time. After inhalation the rats were kept in an air conditioned room until the sacrification and were given again the pellet and water.

As control group the rats breathing air in the exposure chamber were used. As unrestrained group (free), the rats bred in the air conditioned room under the normal breeding condition were used.

\section{Counting of cell number}

Aliquots of the washings were counted in hemocytometer to obtain the total number of cells present. 

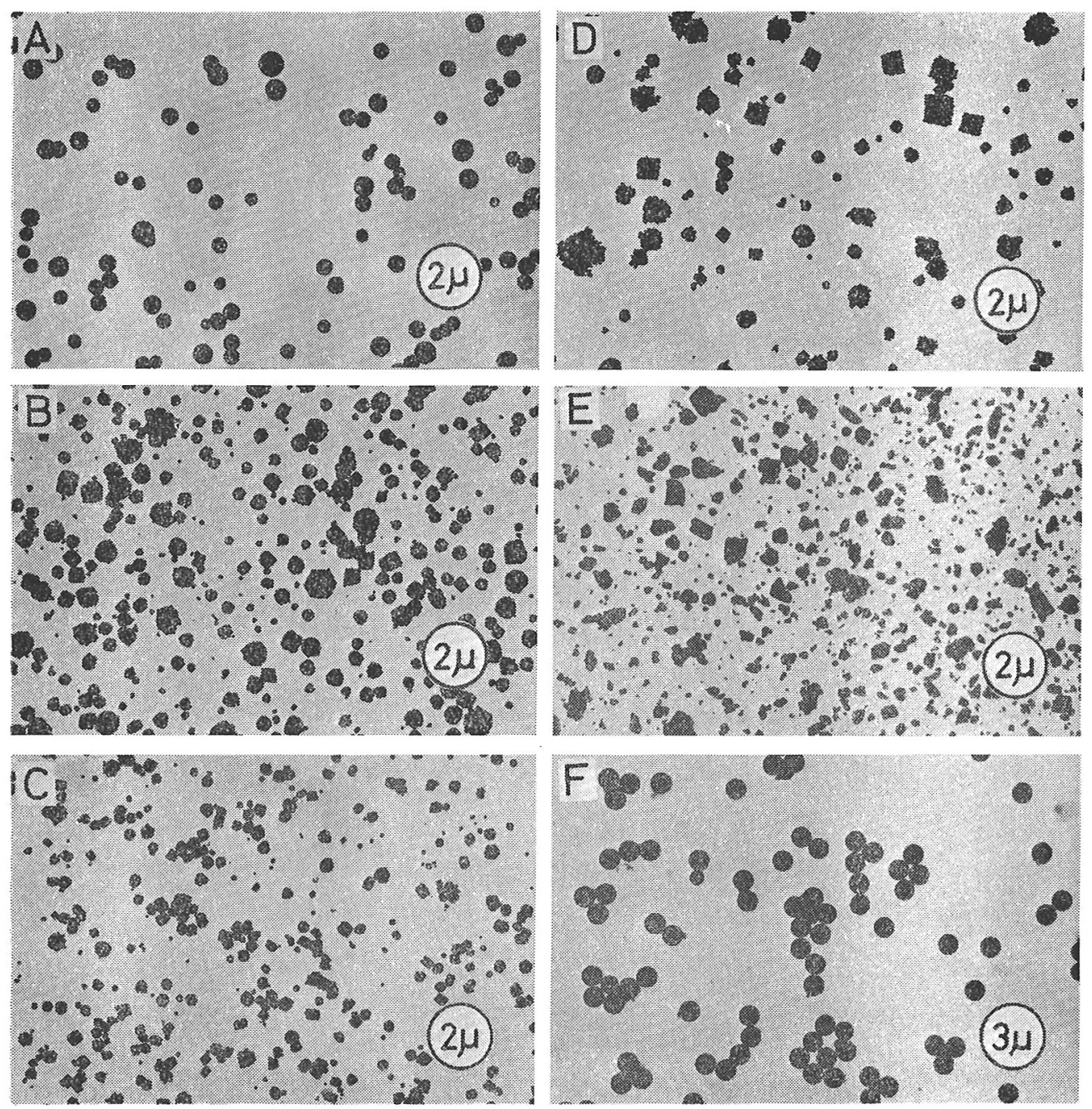

Fig. 2. Electronmicrographs of metallic fumes and dust.
$\mathrm{A}: \mathrm{Pb}$
D: $\mathrm{Cd}$
B: $\mathrm{Sb} \mathrm{I}$
$\mathrm{E}: \mathrm{CaCO}_{3}$
C: $\mathrm{Sb}$ II
F: PVC

The determination of radioactivity

To the tubes containing 1 million macrophages suspended in Tyrode's solution $0.2 \mu \mathrm{C}$ of ${ }^{14} \mathrm{C}$-L-leucine was added and these tubes were incubated at $37^{\circ} \mathrm{C}$ for various periods. After incubation the incorporation was stopped with the addition of $10 \%$ TCA solution containing $0.01 \mathrm{M}$ cold leucine. The precipitated protein was purified for counting by the method of Ravinovitz et al.6) The purified protein was dissolved in $88 \%$ formic acid. Aliquot and the scintillator were added to each vial and the radioactivity was determined with liquid scintillation counter. 


\section{ALVEOLAR MACROPHAGE AND METALLIC FUME}

\section{RESULTS}

\section{Toxic Doses of the Particles Used in Inhalation Experiment to Macrophage in Vitro}

For the determination of the toxic doses of the particles used in inhalation experiment, varying amounts of each particle were added to the peritoneal macrophages at a concentration of 5 million cells. After $2 \mathrm{hr}$ incubation, ${ }^{14} \mathrm{C}$-leucine incorporation into the cell protein was determined. The toxic dose was expressed as the amount of particle necessary for depression by $50 \%$ of ${ }^{14} \mathrm{C}$-leucine incoporation into the cell protein of the control cultures. The sizes of the particles used in above experiments were nearly the same as those of the particles generated in inhalation experiments. The toxic dose of $\mathrm{CaCO}_{3}$ or PVC was above $1000 \mu \mathrm{g}$, while it was $18 \mu \mathrm{g}$ for Sb fume, $60 \mu \mathrm{g}$ for $\mathrm{Cd}$ fume and $700 \mu \mathrm{g}$ for $\mathrm{Pb}$ fume.

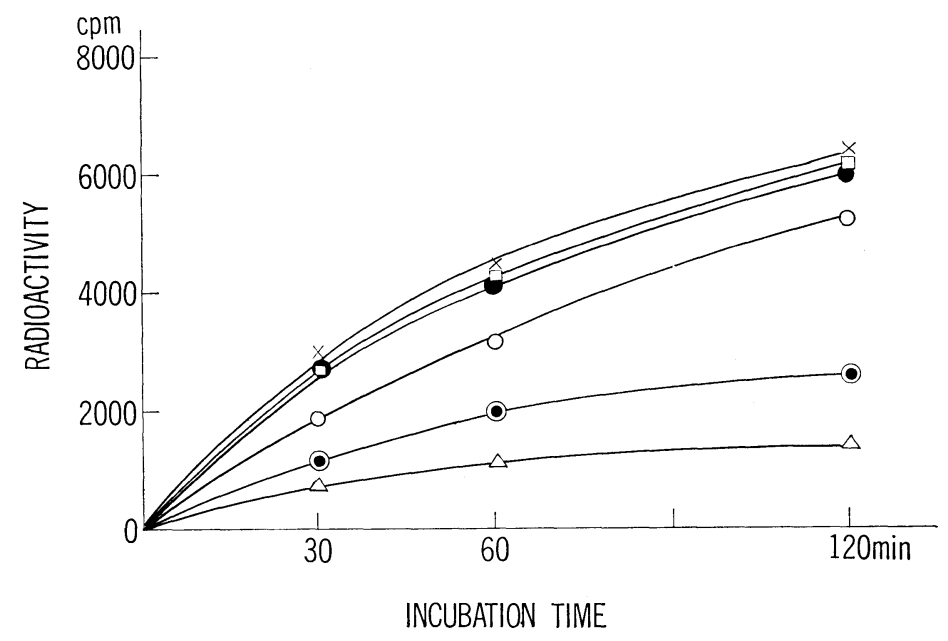

Fig. 3. Time-rate curves of ${ }^{14} \mathrm{C}$-leucine incorporation into the alveolar macrophage with various fume or dust.

$\begin{array}{llll}\times \longrightarrow \times & \text { control } & \bigcirc \longrightarrow \bigcirc & \mathrm{Pb} \\ \square-\square & \mathrm{CaCO}_{3} & \odot \longrightarrow & \mathrm{Cd} \\ -\square & \mathrm{PVC} & \triangle \longrightarrow & \mathrm{Sb}\end{array}$

In the Fig. 3, the time rate curve of ${ }^{14} \mathrm{C}$-leucine incorporation into the alveolar macrophage added with the above fume or dust were shown. The proportion was particles $100 \mu \mathrm{g} / 2 \times 10^{6}$ cells. The incorporation of ${ }^{14} \mathrm{C}$-leucine into cell markedly decreased $30 \mathrm{~min}$ after the addition of $\mathrm{Sb}$ fume or $\mathrm{Cd}$ fume and after $2 \mathrm{hr}$ had almost completely stopped, whereas the incorporation of control culture and of the culture with $\mathrm{CaCO}_{3}$ or $\mathrm{PVC}$ increased with the increasing time. $\mathrm{By}$ the $\mathrm{Pb}$ fume the incorporation of ${ }^{14} \mathrm{C}$-leucine into cell protein was slightly inhibited in comparison with that of control. 


\section{K. KOSHI, K. HOMMA AND H. SAKABE}

\section{Inhalation Experiments}

Every 3 rats were sacrificed $1 \mathrm{hr}$ and $21 \mathrm{hr}$ after inhalation. The concentration, exposure time and size of fume or dust during inhalation were showen in Table 1.

Table 1. Concentration, exposure time and size of particles used in inhalation experiments.

\begin{tabular}{|c|c|c|c|c|c|c|}
\hline & \multirow{2}{*}{$\begin{array}{l}\text { Mean con- } \\
\text { centration of } \\
\text { fume or dust } \\
\mathrm{mg} / \mathrm{m}^{3}\end{array}$} & \multirow{2}{*}{$\begin{array}{l}\text { exposure } \\
\text { time } \\
(\mathrm{min})\end{array}$} & \multicolumn{4}{|c|}{ Particle size } \\
\hline & & & $\begin{array}{c}\mathrm{AMD} \\
(\mu)\end{array}$ & $\underset{(\mu)}{\operatorname{MMD}}$ & $\begin{array}{c}\mathrm{CMD} \\
(\mu)\end{array}$ & $\sigma_{g}$ \\
\hline Control I & $\begin{array}{l}\text { Exhaustion } \\
28.3 \mathrm{l} / \mathrm{min}\end{array}$ & 90 & - & - & - & - \\
\hline Control II & " & 90 & - & - & - & - \\
\hline $\mathrm{Pb} \quad \mathrm{I}$ & 42.1 & 90 & 1.18 & 0.35 & 0.28 & 1.32 \\
\hline $\mathrm{Pb}$ II & 48.3 & 90 & 1.80 & 0.53 & 0.32 & 1.50 \\
\hline $\mathrm{Sb} \quad \mathrm{I}$ & 88.4 & 90 & 1.30 & 0.50 & 0.20 & 1.74 \\
\hline $\mathrm{Sb}$ II & 32.0 & 90 & 0.93 & 0.36 & 0.15 & 1.71 \\
\hline $\mathrm{Cd}$ & 24.7 & 30 & 2.10 & 0.72 & 0.37 & 1.60 \\
\hline $\mathrm{CaCO}_{3}$ & 81.2 & 90 & 2.60 & 1.58 & 0.44 & 1.92 \\
\hline PVC & 120.0 & 90 & 3.70 & 3.76 & 1.77 & 1.65 \\
\hline
\end{tabular}

AMD: Aerodynamic median diameter

MMD: Mass median diameter

CMD: Count median diameter

$\sigma_{g}: \quad$ Geometric standard deviation

$\sigma_{g}$ values of all experiment group except $\mathrm{Pb}$ I experiment group were caliculated from AMD obtained by Andersen sampler, $\sigma_{g}$ value of $\mathrm{Pb}$ I experiment group was calculated from CMD obtained by electronmicrograph.

\section{Macroscopic findings and weights in the lung after inhalation}

There were no pathological findings in the lungs of $\mathrm{CaCO}_{3}, \mathrm{PVC}$ or $\mathrm{Pb}$ group macroscopically. A few bleeding spot of a pinhole size on the lung surface $21 \mathrm{hr}$ after inhalation of $\mathrm{Sb}$ fume were observed. The lungs had bleeding flecks of a few square $\mathrm{mm}$ area $21 \mathrm{hr}$ after inhalation of $\mathrm{Cd}$ fume.

The weights of lungs in various experimental groups were shown in Fig. 4. There were no significant differences between the weights of lungs of control and those of lungs of $\mathrm{CaCO}_{3}, \mathrm{PVC}$ or $\mathrm{Pb}$ group. The weights of lungs in $\mathrm{Sb}$ group slightly increased and the weights of lungs in the Cd group significantly increased $21 \mathrm{hr}$ after inhalation.

2. The number of macrophages lavaged from lung after the inhalation of various fume or dust

The number of macrophages lavaged from the lungs of rats after inhalation of various 
ALVEOLAR MACROPHAGE AND METALLIC FUME

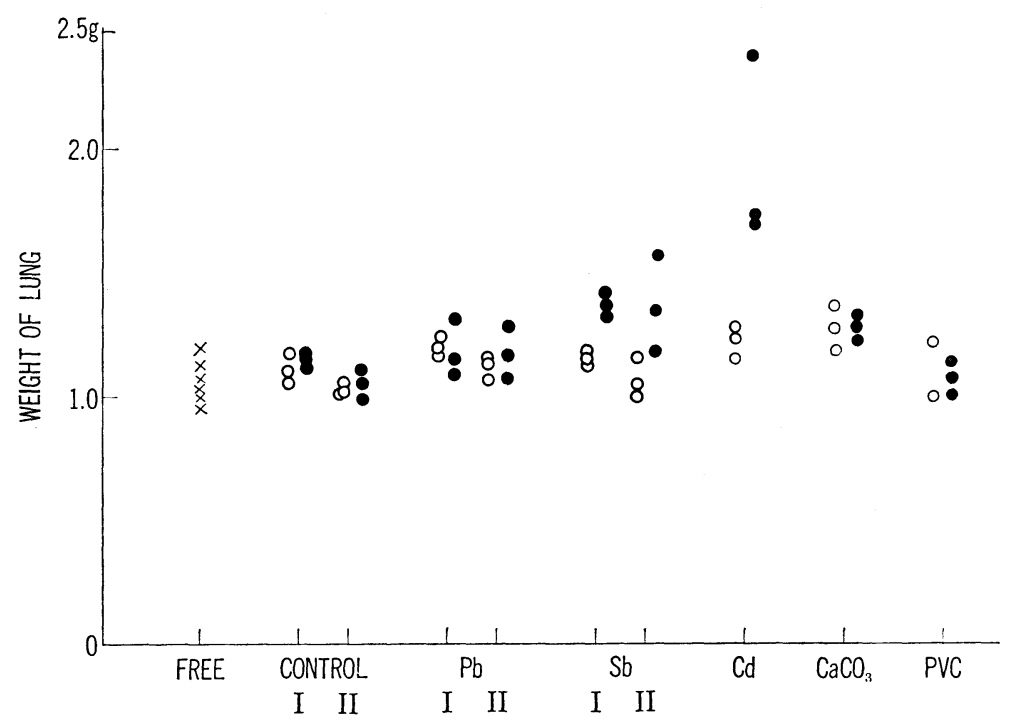

Fig. 4. The weights of lungs after inhalation.

$\bigcirc$ : $1 \mathrm{hr}$ after inhalation

-: $21 \mathrm{hr}$ after inhalation

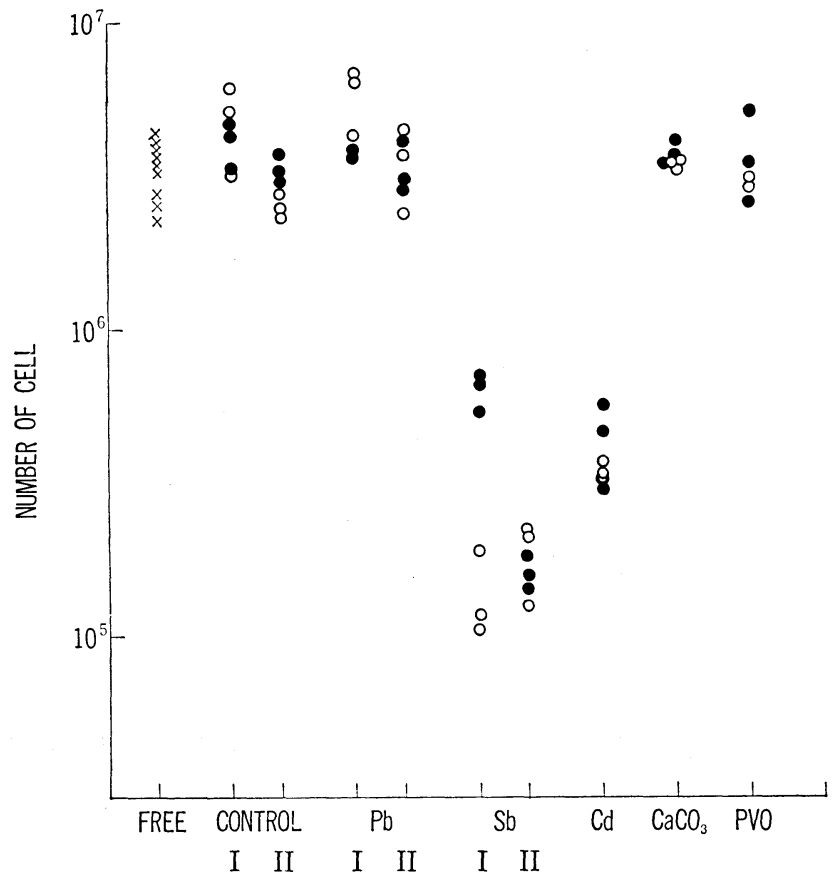

Fig. 5. The number of cells lavaged from lung after inhalation

$\bigcirc: 1 \mathrm{hr}$ after inhalation

- $21 \mathrm{hr}$ after inhalation 


\section{K. KOSHI, K. HOMMA AND H. SAKABE}

fume or dust were shown in Fig. 5. The number of cells washed from the lungs of the rats that had inhaled $\mathrm{Sb}$ or $\mathrm{Cd}$ fume significantly decreased in comparison with that of control rat breathing air in the exposure chamber. While there were no significant differences between the number of the cells washed from lungs of control or unrestained group and that of $\mathrm{Pb}, \mathrm{CaCO}_{3}$ or $\mathrm{PVC}$ group. $(\alpha>0.25)$ In all the experimental group except $\mathrm{Sb}$ and $\mathrm{Cd}$ groups there were no significant differences between the number of cell $1 \mathrm{hr}$ after inhalation and that $21 \mathrm{hr}$ after inhalation. $(\alpha>0.25)$ In the case of $\mathrm{Sb}$ experiment many destroyed cells were observed in the washing fluid. In the experiment of Cd inhalation the number of lavaged cells decreased but $1 \mathrm{hr}$ after inhalation the destroyed cells were not observed in the washing fluid. In the case of Cd group $21 \mathrm{hr}$ after inhalation, some destroyed cells were observed in the lavaged fluid and the blood red cells were also found by about ten times the number of those in lavaged fluid in

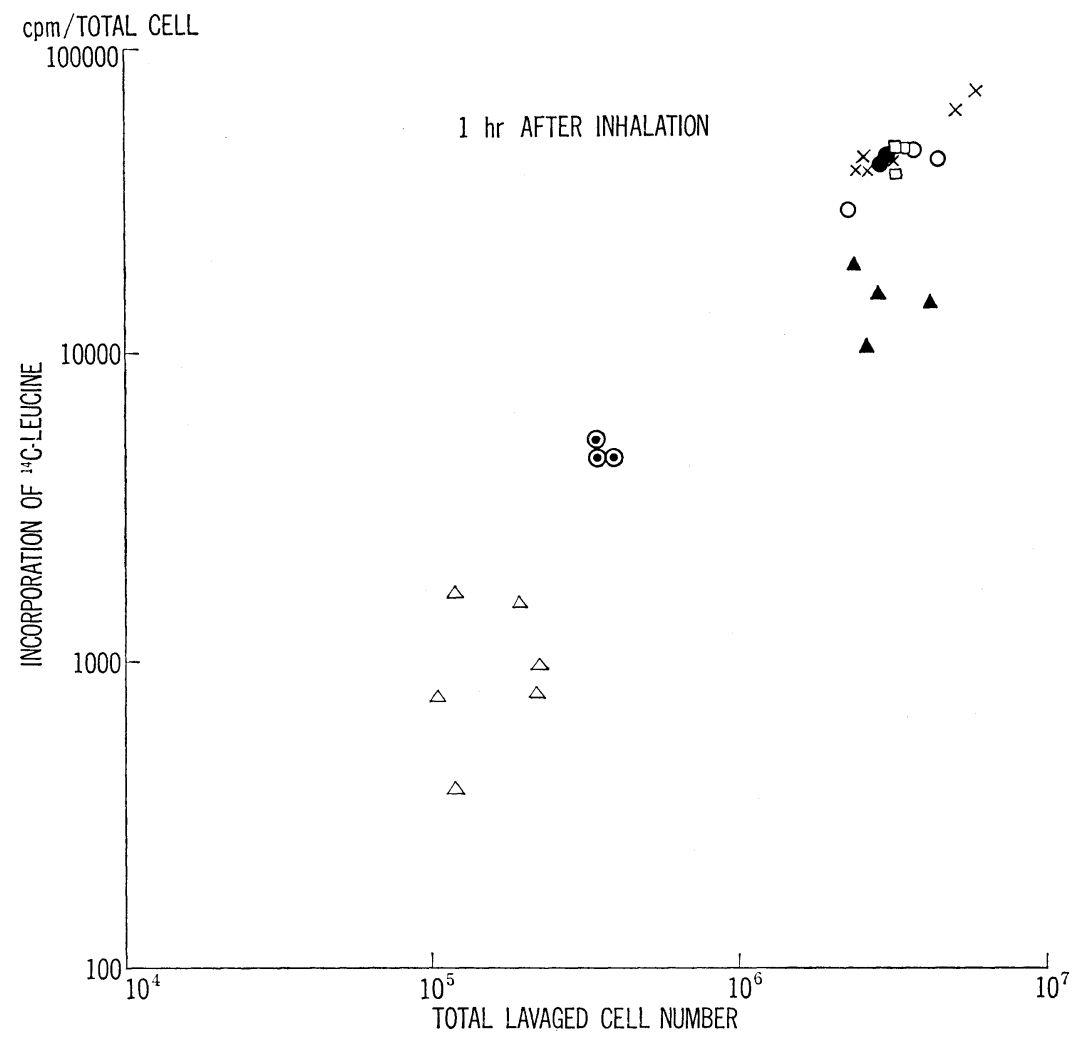

Fig. 6. The relation between ${ }^{14} \mathrm{C}$-leucine incorporation into total cell and total lavaged cell number.
$\Delta-\boldsymbol{\Delta}$ free
$\mathrm{O}-\mathrm{Pb}$
$\times \longrightarrow$ control
$\odot-\odot \mathrm{Cd}$
$\square-\square \quad \mathrm{CaCO}_{3}$
$\triangle \longrightarrow \mathrm{Sb}$
-1- PVC 


\section{ALVEOLAR MACROPHAGE AND METALLIC FUME}

the other experimental group.

\section{Incorporation of ${ }^{14} \mathrm{C}$-leucine into macrophage}

The relation between the incorporation of ${ }^{14} \mathrm{C}$-leucine into total lavaged cells and the number of total lavaged cell in each experimental group was shown in Figs. 6 and 7. As shown in Fig. $6,1 \mathrm{hr}$ after inhalation there was a linear correlation between the incorporation of ${ }^{14} \mathrm{C}$-leucine and cell number. That is, ${ }^{14} \mathrm{C}$-leucine incorporation into cell increased with increasing cell number. But although the cell number in the groups exposed to $\mathrm{Pb}, \mathrm{CaCO}_{3}, \mathrm{PVC}$ and control and unrestrained groups did not significantly differ, there was some difference between the incorporation of ${ }^{14} \mathrm{C}$-leucine into cell in the groups exposed to $\mathrm{Pb}, \mathrm{CaCO}_{3}, \mathrm{PVC}$ or control group and that of unrestrained group $1 \mathrm{hr}$ after inhalation. $(\alpha=0.065)$ The incorporation value in the former was

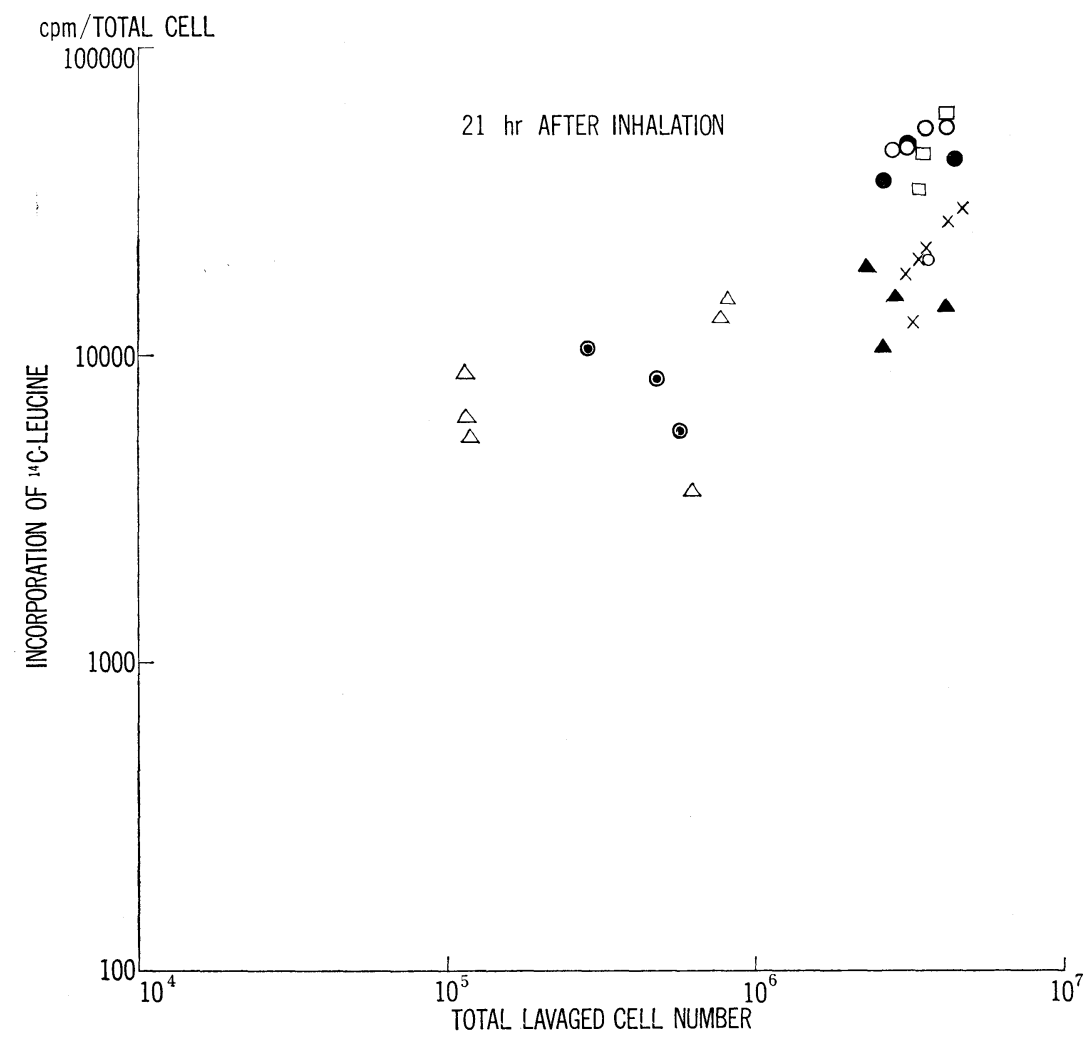

Fig. 7. The relation between ${ }^{14} \mathrm{C}$-leucine incorporation into total cell and total lavaged cell number.
$\boldsymbol{\Delta}-\boldsymbol{\Delta}$ free
$\mathrm{O}-\mathrm{Pb}$
$\times$ - control
$\odot-\bigcirc \mathrm{Cd}$
$\square-\square \quad \mathrm{CaCO}_{3}$
$\triangle \longrightarrow \mathrm{Sb}$
-— PVC 


\section{K. KOSHI, K. HOMMA AND H. SAKABE}

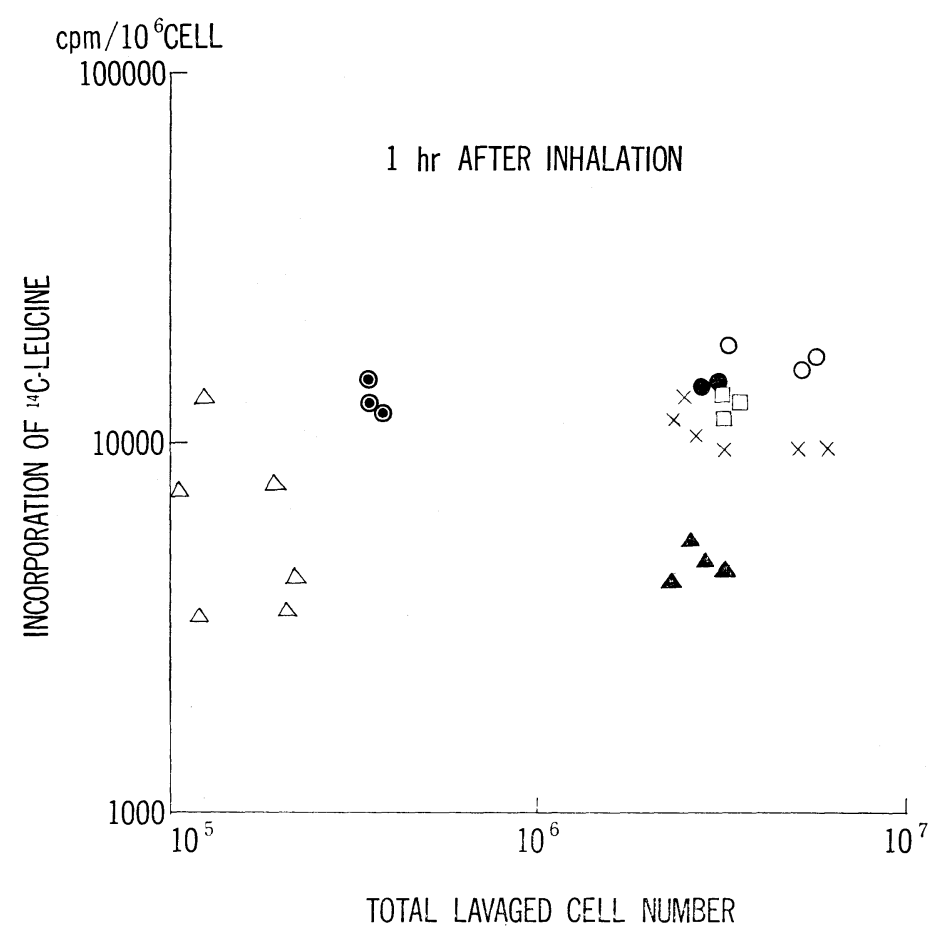

Fig. 8. The relation between ${ }^{14} \mathrm{C}$-leucine incorporation per $10^{6}$ cells and total lavaged cell number.

$\begin{array}{llll}\Delta-\Delta & \text { free } & \bigcirc-\bigcirc & \mathrm{Pb} \\ \times-\times & \text { contral } & \odot-\odot & \mathrm{Cd} \\ \square-\square & \mathrm{CaCO}_{3} & \Delta-\Delta & \mathrm{Sb} \\ -\square & \text { PVC } & \end{array}$

higher than that in the latter.

As shown in Fig. 7, $21 \mathrm{hr}$ after inhalation the incorporation of ${ }^{14} \mathrm{C}$-leucine into cell in $\mathrm{Pb}, \mathrm{CaCO}_{3}$ or $\mathrm{PVC}$ group did not change from that $1 \mathrm{hr}$ after inhalation. $(\alpha>0.25)$ While in $\mathrm{Cd}$ and $\mathrm{Sb}$ group the incorporation of ${ }^{14} \mathrm{C}$-leucine into cell increased in comparison with that $1 \mathrm{hr}$ after inhalation.

In order to ascertain the incorporation per cell the relation between the incorporation of ${ }^{14} \mathrm{C}$-leucine per $10^{6}$ cells and the number of total cell were shown in Figs. 8 and 9. As shown in Fig. 8, the incorporation of ${ }^{14} \mathrm{C}$-leucine per $10^{6}$ cells $1 \mathrm{hr}$ after inhalation in all the experimental group except $\mathrm{Sb}$ group and unrestrained group showed almost the same value. In $\mathrm{Sb}$ group and unrestrained group ${ }^{14} \mathrm{C}$-leucine incorporation per $10^{6}$ cells was lower than those of the other groups. As shown in Fig. 9, $21 \mathrm{hr}$ after inhalation there was a negative correlation between the cell number and ${ }^{14} \mathrm{C}$-leucine incorporation per $10^{6}$ cells. The incorporation of ${ }^{14} \mathrm{C}$-leucine per cell in $\mathrm{Sb}$ group $21 \mathrm{hr}$ after inhalation remarkably increased in comparison with that $1 \mathrm{hr}$ after inhalation. This tendency was also seen in $\mathrm{Cd}$ group. And $21 \mathrm{hr}$ after inhalation there was no significant 


\section{ALVEOLAR MACROPHAGE AND METALLIC FUME}

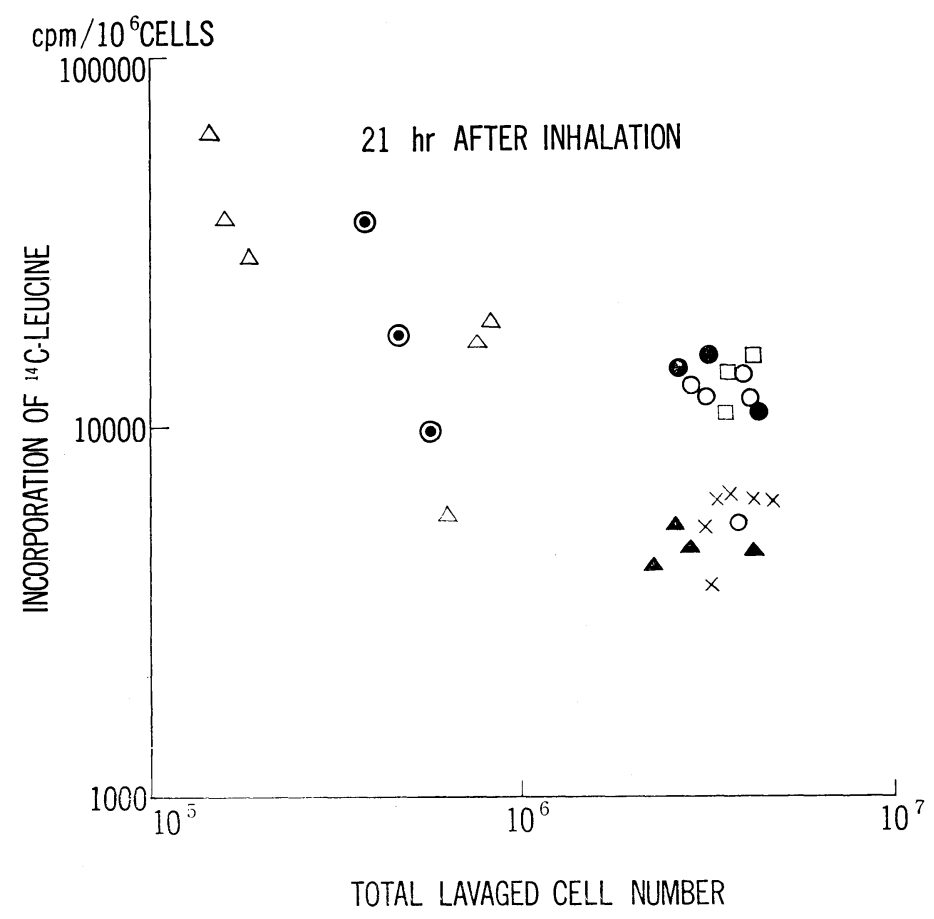

Fig. 9. The relation between ${ }^{14} \mathrm{C}$-leucine incorporation per $10^{6}$ cells and total lavaged cell number.

$\begin{array}{llll}\Delta-\Delta & \text { free } & \bigcirc-\bigcirc & \mathrm{Pb} \\ \times-\times & \text { contral } & \odot-\odot & \mathrm{Cd} \\ \square-\square & \mathrm{CaCO}_{3} & \Delta-\triangle & \mathrm{Sb} \\ -\square & \mathrm{PVC} & & \end{array}$

difference between the incorporation of ${ }^{14} \mathrm{C}$-leucine into cell in control group and that in unrestrained group. In $\mathrm{Pb}, \mathrm{CaCO}_{3}$ and $\mathrm{PVC}$ groups the incorporation values were almost equal $(\alpha>0.25)$ and these values were higher than those of control or unrestained group.

\section{Discussion}

The cell toxicity of the particles used in inhalation experiment to macrophage in vitro was the most toxic in $\mathrm{Sb}$ fume of all the samples, being followed by $\mathrm{Cd}$ fume and then by $\mathrm{Pb}$ fume. The particles of $\mathrm{CaCO}_{3}$ or $\mathrm{PVC}$ were practically inert to macrophage. It may be assumed that the variation of the number of alveolar macrophage lavaged from lung after inhalation were correlated with the cellular toxicity of the particles in vitro. That is, in the case of inhalation of $\mathrm{Sb}$ fume which had strong toxic action in vitro, only $1 \mathrm{hr}$ after inhalation the number of the cells lavaged from lung remarkably decreased. Twenty-one hours after inhalation the cell number of lavaged macrophage 


\section{K. KOSHI, K. HOMMA AND H. SAKABE}

somewhat recovered in Sb I group $(1.30 \mu, \mathrm{AMD})$ but in Sb II group (0.93 $\mu, \mathrm{AMD})$ it did not recover. These differences may be produced by size of fume.

In many studies ${ }^{78}$ ) the cell number of lavaged macrophage was expressed as the number per $g$ lung but we used per lung because lung weights of control rats have few variance and futhermore the weight of lung largely changed by the damaging effect of the inhaled particles.

In the case of the inhalation of $\mathrm{Cd}$ fume, the exposure time was used for $30 \mathrm{~min}$ because in the previous research ${ }^{10}$ ) it was observed that the $\mathrm{LD}_{50}$ of the inhaled metallic fume of $1.3 \mu$ (AMD) in the size for $30 \mathrm{~min}$ was $25 \mathrm{mg} / \mathrm{m}^{3}$ for rats. That is, in order to survival up to $21 \mathrm{hr}$ after inhalation of $\mathrm{Cd}$ fume, the concentration of $\mathrm{Cd}$ fume should be lower than $25 \mathrm{mg} / \mathrm{m}^{3}$. But, the generation of lower concentration of $\mathrm{Cd}$ fume could not be stabilize during inhalation time. Therefore, the exposure time was shortened.

LaBell \& Brieger ${ }^{11)}$ showed that the inhalation of carbon particles increased the number of free cells in lung. But under our experimental condition the increase of the number of free cells in lung was not observed. The method of washing of lung was different among the investigators. LaBelle \& Brieger ${ }^{11,12)}$ used only one time washing, Gross $^{13)}$ used two times, while Brain ${ }^{7,8)}$ chose twelve times and Bingham ${ }^{9,14)}$ used 7 times or 9 times. In the present paper we used 4 times washing. We determined using 5 rats about washing procedure and it was confirmed that the ratio of the number of cells recovered in the 4 times wash to that in the 10 times wash was almost constant and futhermore in the ten times washing the period of time of procedure was too long to keep the cellular activity. Therefore, we used the 4 times washing.

On the experimental group that alveolar macrophage was destroyed by inhalation ${ }^{14} \mathrm{C}$-leucine incorporation into cell increased $21 \mathrm{hr}$ after inhalation. In order to ascertain this cause the destroyed material of cells which was produced by ultrasonic were added to intact macrophage and the incorporation of these cellular system was determined. In this cellular system the incorporation of ${ }^{14} \mathrm{C}$-leucine into macrophage did not increases. Therefore, it may be assumed that this phenomenon was the reaction in vivo. In connection with this phenomenon, recently Aoki and Watanabe ${ }^{15)}$ showed cinematomircoscopically that the activity of alveolar macrophage lavaged from lung of rabbit exposed to ozone was damaged $3 \mathrm{hr}$ after exposure while $24 \mathrm{hr}$ after exposure it did not change from that of control or rather showed a higher activity.

One hour after inhalation the incorporation of ${ }^{14} \mathrm{C}$-leucine into cell of control group increased in comparison with that of unrestrained group. But, $21 \mathrm{hr}$ after inhalation there was no difference between the incorporating activity of control group and that of unrestrained group. The cause of this phenomenon is obscure.

\section{ACKNOWLEDGEMENT}

The authors are very grateful to Mrs. K. Suzuki for her skilled technical assistance. 


\section{ALVEOLAR MACROPHAGE AND METALLIC FUME}

\section{REFERENCE}

1) Koshi, K., Hayashi, H., Hamada, A. and Sakabe, H. (1961). Bull. Nat. Inst. Ind. Health, 6, 10.

2) Sakabe, H., Koshi, K. and Hayashi, H. (1971). Inhaled Particles III (Edited by Walton, W.H.), p. 423, Unwin Brother Ltd, Surrey.

3) Koshi, K. and Sakabe, H. (1974). Jap. J. Ind. Health, 16, 328. (in Japanese)

4) Homma, K. (1966). Ind. Health, 4, 129.

5) Homma, K. (1975). Jap. J. Hyg. 30, 323. (in Japanese)

6) Ravinovitz, M., Olson, M.E. and Greenberg, D.M. (1954). J. Biol. Chem., 210, 837.

7) Brain, J.D. and Frank, N.R. (1968). J. Appl. Physiol. 25, 63.

8) Brain, J.D. (1971). Inhaled Particles III (Edited by Walton, W.H.), p. 209, Unwin Brother Ltd, Surrey.

9) Bingham, E., Barkley, W., Zerwas, M., Stemmer, K. and Taylor, P. (1972). Arch. Environ, Health, 25, 406.

10) Yoshikawa, H. and Homma, K. (1974). Jap. J. Ind. Health, 16, 212. (in Japanese)

11) LaBelle, C.W. and Brieger, H. (1960). Arch. Environ. Health, 1, 423.

12) LaBelle, C.W. and Brieger, H. (1961). Inhaled Particles and Vapours (Edited by Davies, C.N.), p. 356. Pergman Press, Oxford.

13) Gross, P., de Treville, R.T.P., Tolker, E.B., Kaschak, M. and Babyak, M.A. (1969). Arch. Environ. Health, 18, 174.

14) Bingham, E., Pfitzer, E.A., Barkley, W. and Radford, E.P. (1968). Science, 162, 1297.

15) Aoki, T. \& Watanabe, M. (1974). Metabolism and Disease, 11, 1601. (in Japanese) 